\title{
Stamp Out N-------L------W-------!
}

BY NEAL HARLOW

IT MIGHT BE SUPPOSED that in the academic world libraries would be regarded as wanted, inevitable, and required; with an indispensable commodity and a captive audience, what more proper monopoly could there be? Too, the academic library is everywhere vaunted as "the scholar's workshop" and "the heart of the university," and head librarians, both in hope and vanity, have been known to regard it as true. But while this blessed doctrine is widely heralded from desk and lectern, it is most formally observed on such holy days as Commencement.

The library is indeed the heart of the university, circulating books and other materials and keeping a stream of vital services coursing through the institution's veins; but much of the establishment's muscle, meat, and fat, it has often been observed, seems to settle elsewhere (and fat, we are reminded, is harmful in the blood). There are of course other circulatory systems (like the lymphatics), and one of these carries through the academic body that yellow, salty ingredient which enriches the blood stream, combats infection, and is filtered through tiny regulatory glands called budgets. Quite an independent set of valves controls this vital flow, and if the normal fiscal processes fail adequately to sustain the blood and heart, this will not prove fatal to the whole university for it can survive indefinitely through the animation of any of its parts.

This is no fable, for an academic library must fight for its life as does any other, and it is not accidental when some success is achieved. I shall not attempt to analyze here why university presidents, deans, and professors do not volunteer their salaries and expense accounts in unstinted support for library service; it is enough to know that however vital it may
Mr. Harlow is Dean of the Graduate School of Library Service at Rutgers University and President of ACRL. This paper was read to a meeting of the ALA National Library Week Committee at Chicago, January $29,1964$.

be to them, it is off-center to their main concern. And if academic libraries are not the primary concern of those who depend upon them, how much more oblique are they likely to be to the attention of other people!

This year ALA President Wagman and National Library Week both turn the spotlight upon academic libraries as being particularly needy of attention and support, and I, too, wish to champion this wide appeal. Academic libraries are crucially important, important enough to warrant your interest as well as mine, your interest in academic libraries even at some sacrifice to your own dearest concern, a concern which must embrace libraries of all types and levels if we are together to approximate the services required.

Education is a means of effecting or avoiding change or of dealing with it; it is an instrument by which we adjust to our environment. Sometimes it is repressive, maintaining a status quo or enabling man to live peacefully with it, and sometimes it is liberating, centered in the individual and advancing with him to some self-determined point. As environment changes, society must take this into account and compensate through its educational pattern. When the rate of change becomes faster than the normal process of learning and relearning, education must build into the individual some means of self-adjustment; the gap between education and change can be narrowed in no other way. 
Essentially, we believe that everything that happens, however unexpected or fantastic, derives from some cause which can ultimately be understood. Learning as a key to meaning must therefore supplant education as a prop to conformity; specific knowledge becomes obsolete, but the process of extending and interpreting it is infinite. What we call "brain power" is the human capability of acquiring and reevaluating a store of knowledge by using tools and a process which have been mastered through education; it is one of the basic resources of an advanced society. It functions at many levels but is necessary in some degree to every intelligent citizen, and its discovery and development affects his place and contribution. The importance of education, and particularly of higher education, is therefore plain to see.

It is indicative that the level of what is called "functional literacy" has lately been advanced from five to eight years of formal schooling. Where a high school diploma was once required, no less than a bachelor's degree will now often do, and the degree has acquired new economic and social implications. Increasing the accessibility of colleges and universities satisfies the democratic ideal of maximum opportunity for individual development. World conditions, too, foster higher education to provide competence and skills in competition with rivals, and education and defense are officially joined in federal law. Many influences have of late raised education to a highly urgent state at all levels, lent a less-jaundiced color to intellectual attainment, and made it seem reasonable in many places to devote up to half of local public funds to formal schooling.

For a number of years we have watched with pleasure, anxiety, and disbelief the steady increase in college enrollment, in seeming obedience to some wild surmise. The graph has become familiar: in 1850 there were twelve thousand college students, in 1900 , two hundred thirty-eight thousand, and in 1950, two million four hundred thousand; then in only twelve years between 1950 and 1962 the number almost doubled, to four million two hundred seven thousand; and it is predicted that in the eight years leading up to 1970 it will rise to seven million. My university, in a state 175 miles long, conservatively estimates growth from its present thirteen thousand students to forty-six thousand by 1980 (the outside figure being seventy-five thousand, with twenty-five thousand on an adjacent campus for which the land is not yet assured.

It seems obvious that we are not going to expand resources that fast. There will be shortages of space, teachers, and libraries, and some millions of persons in the United States will be taken care of in new local junior colleges and technical schools rather than in four-year colleges and universities. Some thirty to forty of these junior schools are being founded every year, and it has been estimated that by 1970 about 70 per cent of all entering freshmen will be accommodated therein. These "higher" (as contrasted with "high") schools may pose the most important and gravest educational problems of the immediate future: ${ }^{1}$ often without academic tradition, governed by local public school officers who are oriented toward secondary education rather than the university, supported largely by local tax funds, emphasizing terminal programs of training for technical positions, and gauging their success by how many of their graduates are placed in local industry, they may not fulfill the primary mandate of higher education. When wisdom and suppleness of mind are most required, it may be that the first steps in higher education will be directed toward training rather than education, toward developing immediately practical technical skills to the exclusion of that supremely practical skill of dealing with ideas. A failure to develop intellectual indepen-

${ }^{1}$ See Frederick J. Wagman, "Library Requirements of the Modern College," Library Quarterly, XXXI (January 1961), 33-44. 
dence in students and the basic habit and means of acquiring information and answers in books will cut them off from any dependable source of intellectual supply when they leave the organized support of the school.

The library mirrors the problems of the educational scheme. Teachers with heavy schedules, large classes, perhaps with experience only in secondary schools, will have no greater opportunity to "teach with books" at the higher level than they did in the lower grades, and not only do many community colleges lack the "carefully selected collection of at least 20,000 volumes," specified by the Standards, they may open with nearly empty shelves, counting upon public or other libraries to fill the gap, and may provide very inadequate funds even for respectable current growth. The Standards for Junior College Libraries, ${ }^{2}$ also prescribe two professional librarians for effective service to enrollments up to five hundred students, and then state that it is their professional duty to participate actively in the educational program of the institution, give instruction in library use and bibliographic assistance to faculty, hold memberships in committees, and carry on other activities. Dr. Wagman has noted that "if both these librarians were freed of all duties relating to book selection, ordering, cataloging, and administration, if they never conferred with the faculty or a library committee or answered the phone, if they should spend every second of their time helping and advising students, and could schedule appointments as a dentist does, they would have 9.6 minutes per week for each of the five hundred." 3 And statistics do not often bear out the existence of these two. Nevertheless, working with the limited number of students whom they can reach, the librarian can be one of the strongest influences in the community college for

2 CRL, XXI (May 1960), 199-206.

Op. cit., p. 37 . self-education (hopefully assisted by a good book store).

The old-line colleges and universities do not remain unchanged. There are large classes, some in scores of sections, reading textbooks, outlines, excerpts, and syllabi, and shunted onto new mechanical devices-all specifically useful but directing attention away from the library, the source of knowledge with an infinite prospect for education beyond the school. Reading, alone, is a highly portable and variable tool, and when motivated by personal interest, disciplined by experience, and sustained by the habitual use of library resources and method, it plays a primary educational role. Greater encouragement must be given to the usury of the book-at a rate of interest above that now considered normal-if we are truly to educate the mind.

Bodily hunger has built-in signals and motivations to ward off starvation, and society has from the start given the bulk of its attention to gratifying physical needs. Now, late in the evolutionary process, when the life of the mind begins to have primary survival value, satisfying the rising demands for intellectual food and exercise must be given at least equal precedence.

Academic institutions have wider responsibilities than are symbolized by the defenses which have sometimes been raised around their intellectual and geographical boundaries. Justified by many fine arguments, even their libraries have been reluctant to accept equal responsibility in cooperation, although gestures in this direction have long been standard practice, chiefly in the form of reference service (largely by telephone) and interlibrary loan (within the academic and research community). But new attitudes toward intellectual development, a wider spectrum of university students, the expansion of research, and financial encouragement from state and federal sources begin to predispose them toward closer affiliation with the rest of the intellectual 
world - at a time, be it said, when a gross enlargement of their primary load takes place. In New York a statewide plan to associate academic, research, and reference libraries to constitute a single network, with state support through direct subsidy or grants-in-aid, seems headed for implementation, and in Pennsylvania, to name one other, college libraries serve (tentatively at least) as local and regional library centers, and the usefulness of creating a statewide resource for reference and research in which academic libraries will be the core is under exploration. The millennium of library service draws nigh when academic libraries in every region proffer their major intellectual stores as stockpiles and supermarkets to support the affluent mind.

The strategy now most urgently required for library development cannot be laid out upon a large-scale map where all the fine details can be clearly seensalaries, recruitment, tax base, central processing, paperbacks, book catalogs, machines. The master plan must be developed at a higher elevation, with the whole continent of library use in view; and with this perspective, our major objectives should be identified, responsibilities assigned, and a schedule adopted, specifying what we have to do. Then we should reach every reader, educator, and politician, every professional man, parent, and citizen, who is making up his mind about libraries (or not giving them a thought) and convince him they are as essential as jobs and schools. Thus, ultimately, we may achieve universal, compulsory library service, based upon the intellectual needs of people rather than upon their more superficially expressed wants.

It is a dereliction on the part of the library profession that no one has yet produced so substantial a plan, for we have ready at hand a powerful protagonist for libraries that can speak to and awaken the very people we ought to reach; this is of course the N. L. W. If (representing libraries of all types) we could consolidate our major hopes, needs, and intentions, and even in a tentative way allow our small-scale objectives and fractional aims, our doubts and uncertainties to be absorbed in a comprehensive, optimum plan, we could use the structure of National Library Week to our great purpose. It is there, like the tide and sun, set in motion by all the national media of communication, and we can utilize its force to generate library service in every sector of the nation.

I am not going to discuss National Library Week (even to say what ACRL is going to do) - others will speak to it better than I-but what I want to reveal to you is that N. L. W. can stand for $\mathrm{Na}$ tional Library Weakness, too, and that when this double meaning becomes firmly fixed in our minds, the importance of National Library Week will be more easily recognized. We are embarrassed that National Library Week in many places promotes patently inadequate services because no decent popular image of libraries exists-a reproach to our unreadiness to propose a library program we can honestly push. My N. L. W. slogan for 1964 will be: Stamp Out National Library Weakness with National Library Week!

\section{Conference Reports in July CRL}

THE OFFICIAL ALA-ACRL CONFERENCE MATERIAL usually not available for publication in CRL until the September issue will be published in the July issue this year. This will necessitate a later publication date than usual; members and subscribers should receive their copies approximately three weeks after the usual date. 